\title{
Korelasi antara Penguasaan Kosakata dengan Kemampuan Menulis Karangan Narasi pada Pelajaran Bahasa Indonesia Siswa Kelas XI SMA Negeri 4 Bengkulu
}

\author{
Kusmaita \\ SMA Negeri 1 Kepahiang \\ Corresponding email: kusmaita@gmail.com
}

\begin{abstract}
Not all of the ability to write narrative essays from Bengkulu 4 High School students still obtained good criteria. This is thought to be caused by the low mastery of the vocabulary. For this reason, testing of the correlation between vocabulary mastery and narrative essay writing skills is needed. The purpose of this study is to: 1) describe the level of mastery of Indonesian vocabulary, 2) describe the level of narrative essay writing ability, and 3) determine whether there is a significant relationship between mastery of vocabulary mastery with narrative essay writing ability. The research method uses the correlation method. Data collection techniques using technical tests. The test instrument trial then the validity and reliability are calculated. Correlation analysis using the Product Moment formula. The results showed that there was a positive correlation between vocabulary mastery and narrative essay writing ability with a value of 0.724 . This is also proved by mastering students 'vocabulary sufficiently and vice versa the results of students' narrative essay writing ability are also categorized sufficiently. This proves that the better the students' vocabulary mastery, the better the ability to write narrative essays.
\end{abstract}

Keywords: correlation, mastery of vocabulary, ability to write narrative essays

\begin{abstract}
Abstrak
Kemampuan menulis karangan narasi siswa SMA Negeri 4 Bengkulu masih belum semuanya memperoleh kriteria baik. Hal ini diduga diakibatkan oleh penguasaan kosakatanya yang masih rendah. Untuk itu, dibutuhkan pengujian terhadap korelasi penguasaan kosakata dengan kemampuan menulis karangan narasi. Tujuan penelitian ini adalah untuk: 1) mendeskripsikan tingkat penguasaan kosakata bahasa Indonesia, 2) mendeskripsikan tingkat kemampuan menulis karangan narasi, dan 3) mengetahui ada tidaknya korelasi yang signifikan antara penguasaan kosakata dengan kemampuan menulis karangan narasi. Metode penelitian menggunakan metode korelasi. Teknik pengumpulan data menggunakan teknis tes. Uji coba intrumen tes kemudian dihitung validitas dan reliabilitasnya. Analisis korelasi menggunakan rumus Product Moment. Hasil penelitian menunjukkan bahwa terdapat korelasi yang positif antara penguasaan kosakata dengan kemampuan menulis karangan narasi dengan nilai sebesar 0,724 . Hal ini dibuktikan juga dengan penguasaan kosa kata siswa dikatagorikan cukup dan sebaliknya hasil kemampuan menulis karangan narasi siswa juga dikatagorikan cukup. Hal ini membuktikan bahwa
\end{abstract}


Korelasi antara Penguasaan Kosakata dengan Kemampuan Menulis Karangan Narasi ...

semakin baik penguasaan kosakata siswa, maka akan baik juga kemampuan menulis karangan narasi.

Kata kunci: korelasi, penguasaan kosakata, kemampuan menulis karangan narasi

\section{PENDAHULUAN}

Setiap individu mempunyai aktivitas batin. Aktivitas itu bersumber pada pikiran, kehendak, dan perasaan. Dalam menyatakan atau mengeluarkan aktivitas batin tersebut diperlukan suatu alat yaitu bahasa sebagai alat komunikasi yang mampu menyampaikan pesan kepada pembaca atau pendengar (Ningrum, Suryadi, \& Wardhana, 2019:242). Hal ini sesuai dengan fungsi bahasa sebagai alat komunikasi, khususnya dalam Mata Pelajaran Bahasa Indonesia siswa dituntut untuk mampu berkomunikasi secara lisan dan tulis (Noermanzah dkk., 2018:172). Sebagai alat komunikasi, bahasa harus mampu menimbulkan adanya saling mengerti antara penutur dengan pendengar atau penulis antara penulis dengan pembacanya dengan memperhatikan retorika berbahasa dari aspek ethos (karakter), pathos (hubungan emosional), dan logos (bukti logis) (Noermanzah, 2016:10).

Dengan bahasa sebagai mediumnya, seseorang dapat mengintrospeksi dirinya pada waktu menghadapi konflik mental. Dengan bahasa seseorang dapat menguji kelurusan jalan pikiran orang lain, pada hakikatnya ia sendiri sedang berusaha mengasah dan mempertajam pikirannya sendiri. Pernyataan ini sejalan dengan pendapat yang menyatakan bahwa: setiap kata mampu mengungkapkan sebuah gagasan atau ide. Kata-kata merupakan alat penyalur gagasan yang akan disampaikan kepada orang lain. Kata-kata bagaikan pakaian yang dipakai oleh pikiran kita. Setiap kata memiliki jiwa dan setiap anggota masyarakat harus mengetahui jiwa setiap kata, agar ia dapat menggerakkan orang lain dengan katakata yang dipergunakannya (Keraf, 2008:21).

Melalui pendidikan, peserta didik dibina kemampuannya menuangkan ide ke dalam sistem lambang yang berupa bahasa, dan dibina pula kemampuannya menafsirkan sistem lambang bahasa yang disampaikan kepadanya. Kita ketahui, bahwa melalui pengajaran bahasa, siswa diajar untuk mampu memfungsikan bahasa dalam komunikasi dan mampu menjadi penyampai informasi yang baik dan benar (Semi, 1990:102).

Perlu disadari bahwa dalam proses belajar mengajar komunikasi mempunyai peranan yang sangat penting. Komunikasi, dalam hal ini mempergunakan bahasa, adalah alat vital bagi dunia pendidikan. Mereka yang terlihat dalam kegiatan komunikasi itu harus memiliki persyaratan tertentu. Persyaratan itu antara lain harus menguasai sejumlah besar kosakata (perbendaharaan kata) yang dimiliki masyarakat bahasanya. Sebagaimana yang dikemukakan oleh Keraf (2008:22), bahwa penguasaan kosakata merupakan bagian yang sangat penting dalam dunia pendidikan. Prosesnya mungkin lambat dan sulit, tetapi toh orang merasa lega sebab tidak akan sia-sia semua jerih payah yang diberikan. Manfaat dari kemampuan yang diperoleh itu akan lahir dalam bentuk penguasaan terhadap pengertian-pengertian yang tepat dan dapat pula menyampaikan pikiran secara sederhana dan langsung.

Kenyataan menunjukkan bahwa antara kemampuan dan prestasi belajar peserta didik dalam pelajaran Bahasa dan Sastra Indonesia sangat rendah. Walaupun telah bertahun-tahun mereka belajar Bahasa Indonesia, tetapi kemampuan berbahasanya belum memadai. Pernyataan ini sejalan dengan apa yang diungkapkan Supardjato (dalam Tarigan \& Tarigan, 1990:187), bahwa siswa 
menganggap belajar bahasa Indonesia itu mudah dan sering dialami pada rapat kenaikan kelas di SMA, pengajar bahasa Indonesia diminta menaikkan angka bahasa Indonesia menjadi enam, agar beberapa siswa bisa memenuhi syarat untuk naik kelas.

Penguasaan kosakata diprediksi akan mempengaruhi kemampuan menulis karangan narasi siswa. Menulis merupakan kemampuan menuangkan ide ke dalam wacana tulis dengan tujuan menyampaikan pesan kepada pembaca (Supini, dkk. 2019:43 dan Noermanzah dkk., 2018:116). Dalam menuangkan gagasan tersebut, tentunya penulis akan menggunakan kosakata yang ada dalam skematanya. Semakin banyak penguasaan kosakatanya maka akan semakin banyak variasi kosakata yang akan dituangkan dalam tulisan. Apalagi jenis tulisannya berupa karangan narasi yang menuntut penulis untuk menceritakan peristiwa demi peristiwa dengan berbagai jenis tokoh sehingga muncul konflik, hadirnya solusi, dan akhirnya terjadi penyelesaian (Noermanzah, 2018:116). Untuk itu, dalam menulis karangan narasi tentunya tidak terlepas dari penguasaan kosakata dari penulis. Semakin baik penguasaan kosakata maka akan semakin baik dalam menulis karangan narasinya.

Pengaruh penguasaan kosakata terhadap kemampuan menulis sudah diteliti oleh Hasrar dkk. (2018). Penelitian ini khusus pada jenis menulis deskripsi dengan menggunakan bahasa Jerman bukan menulis narasi dengan menggunakan bahasa Indonesia, tetapi dari hasil penelitian ini menunjukkan bahwa penguasaan kosakata berpengaruh terhadap baik tidaknya kualitas hasil menulis siswa. Selain itu, kemampuan penguasaan kosakata juga terbukti memiliki hubungan yang sangat signifikan terhadap kemampuan menulis cerpen siswa (Suryadi \& Milawasri, 2018). Untuk itu, pentingnya penelitian tentang korelasi antara penguasaan kosakata dengan kemampuan menulis karangan narasi siswa kelas XI SMA Negeri 4 Bengkulu.

Dalam penelitian ini akan menguji coba hipotesis adanya korelasi antara penguasaan kosakata dengan kemampuan menulis karangan narasi siswa kelas XI SMA Negeri 4 Bengkulu. Untuk itu, tujuan dalam penelitian ini adalah untuk mengetahui korelasi antara penguasaan kosakata dengan kemampuan menulis karangan narasi siswa kelas XI SMA Negeri 4 Bengkulu. Selain itu juga, akan dijelaskan tingkat penguasaan kosakata siswa kelas XI SMA negeri 4 Bengkulu dan tingkat kemampuan menulis karangan narasi siswa Kelas XI SMA Negeri 4 Bengkulu.

Manfaat dari hasil penelitian ini yaitu: (1) sebagai umpan balik bagi guru dan siswa SMA Negeri 4 Bengkulu dalam meningkatkan hasil pengajaran Bahasa dan Sastra Indonesia melalui penguasaan kosakata dan kemampuan menulis karangan narasi serta (2) sebagai masukan dalam rangka pengembangan pengajaran Bahasa dan Sastra Indonesia khususnya di SMA Negeri 4 Bengkulu.

\section{METODE}

Metode yang digunakan dalam penelitian ini adalah metode korelasi. Metode Metode korelasi merupakan metode penelitian yang berusaha mengkaji hubungan atau korelasi antar variabel yang diuji melalui statistik korelasional (Gall, Gall dan Borg, 2003). Metode ini digunakan untuk mengetahui korelasi penguasaan kosakata dengan kemampuan menulis karangan narasi siswa kelas XI SMA Negeri 4 Bengkulu. 
Korelasi antara Penguasaan Kosakata dengan Kemampuan Menulis Karangan Narasi ...

1. Teknik Pengumpulan Data

Alat pengambilan data yang digunakan dalam penelitian ini yaitu teknis tes. Tes yang penulis gunakan dalam penelitian ini adalah meliputi: (1) tes objektif sebanyak 20 soal dan (2) tes esai untuk penguasaan kosakata bahasa Indonesia sebanyak 10 soal. Kedua bentuk tes itu digunakan untuk mengetahui penguasaan kosakata dan kemampuan menulis karangan narasi siswa kelas XI SMA Negeri 4 Bengkulu. Sedangkan untuk mengetahui kemampuan menulis karangan narasi siswa kelas XI SMA Negeri 4 Bengkulu, penulis menugaskan siswa membuat karangan bentuk narasi.

2. Uji Coba Instrumen Penelitian

a. Validitas

Untuk mengetahui tingkat validitas instrumen yang akan digunakan dalam penelitian terlebih dahulu diuji cobakan (try out). Hasil uji coba dianalisa dengan statistik korelasi product moment dengan rumus angka kasar, yang dikemukakan oleh Hadi (2000:294).

Jika $r_{\text {hitung }}>r_{\text {tabel }}$, N. $1 \%$ atau $5 \%$ item dinyatakan valid

Jika $r_{\text {hitung }}<r_{\text {tabel}}$, N. $1 \%$ atau $5 \%$ item dinyatakan tidak valid

b. Reliabilitas

Untuk mengetahui reliabilitas instrumen yang akan digunakan dalam penelitian ini, digunakan teknik analisis statistik dengan korelasi produck moment yang dikemukakan Hadi (2000:294), dengan kriteria uji reabilitas sebagai berikut.

$$
\begin{aligned}
& r_{n}=\text { tabel } N=10 \% \text { atau } 5 \% \text { maka item-item dinyatakan reliabel } \\
& r_{n}=r_{n} \text { tabel } N=10 \% \text { atau } 5 \% \text { maka item-item dinyatakan reliabel }
\end{aligned}
$$

\section{Teknik Analisis Data Penelitian}

Analisis data yang digunakan dalam penelitian ini adalah analisis deskriptif kuantitatif dengan menggunakan statistik sebagai berikut :

a. Analisis Data untuk Mengetahui Tingkat Penguasaan Kosakata

Untuk menentukan tingkat penguasaan kosakata bahasa Indonesia, penulis menggunakan rumus rata-rata "Mean Aritmatik" (Hadi, 2000).

b. Analisis data untuk Menentukan Kemampuan Menulis Karangan Narasi

Untuk menentukan nilai rata-rata tingkat kemampuan menulis karangan narasi, penulis menggunakan rumus "Mean Aritmatik" (Hadi, 2000).

Kriteria presentase yang dipergunakan untuk mencari gambaran tentang penguasaan kosakata bahasa Indonesia dengan kemampuan menulis karangan narasi dalam pelajaran bahasa Indonesia pada siswa kelas XI SMA Negeri 4 Bengkulu adalah menggunakan kriteria interval tingkat penguasaan skala lima dengan kriteria sebagai berikut.

Tabel 1. Kriteria untuk Menentukan Presentase Skor yang Diperoleh Siswa dalam

Penguasaan Kosakata dan Kemampuan Menulis Karangan Narasi pada Pelajaran Bahasa Indonesia Siswa Kelas XI SMA Negeri 4 Bengkulu

\begin{tabular}{cl}
$\begin{array}{c}\text { Interval Presentase Tingkat } \\
\text { Penguasaan }\end{array}$ & \\
\hline $85 \%-100 \%$ & Baik sekali \\
$75 \%-84 \%$ & Baik \\
$60 \%-74 \%$ & Cukup \\
$40 \%-50 \%$ & Kurang \\
$0 \%-39 \%$ & Gagal
\end{tabular}

(Nurgiyantoro, 2001:363) 
c. Analisis Data Hubungan Penguasaan Kosakata dengan Kemampuan Menulis Karangan Narasi dalam Pelajaran Bahasa Indonesia

Untuk menganalisis hubungan penguasaan kosakata dengan kemampuan mengarang narasi digunakan rumus "Product Moment" sebagai berikut :

$$
r X Y=\frac{N \sum X Y-\left(\sum X\right)\left(\sum Y\right)}{\left\{N \sum Y^{2}-\left(\sum X^{2}\right)\right\}\left\{N \sum Y^{2}-\left(\sum Y^{2}\right)\right\}}
$$

Setelah harga $r$ diketahui, maka untuk uji signifikasi akan dibanding dengan tabel Product moment pada tarap 5\% dengan ketentuan sebagai berikut :

Jika $r$ hit $>$ tabel $\rightarrow$ tolah Ho, terima $\mathrm{Ha}$

Jika $r$ hit $<$ tabel $\rightarrow$ tolah $\mathrm{Ha}$, terima Ho

Selain itu, hasil penghitungan dengan menggunakan rumus Product Moment di atas, digunakan juga menentukan arah korelasi antara penguasaan kosakata dengan kemampuan mengarang narasi siswa kelas XI SMA Negeri 4 Bengkulu, dengan cara membandingkan koefisien $r_{X Y}$ di atas dengan klasifikasi tingkat keeratan hubungan sebagai berikut:

$0,00-0,20$ : hampir tidak ada kolerasi

$0,21-0,40$ : kolerasi rendah

$0,41-0,60$ : kolerasi sedang

$0,61-0,80$ : kolerasi tinggi

0,81 - 1,00 : kolerasi sempurna (Arikunto, 2013)

\section{HASIL}

Pengujian validitas tes menggunakan teknik belah dua yaitu dengan cara membagi dua kelompok dari 20 orang siswa, yaitu 10 orang sebagai kelompok $x$ (ganjil), dan 10 orang sebagai kelompok $Y$ (genap), dengan menggunakan rumus Product Moment. Dari hasil perhitungan tersebut (validitas tes), $r_{\text {hit }}$ sebesar 0,945 sedangkan $r$ tabel $\left(r_{t}\right)$ dengan signifikan $5 \%$ yaitu 0,444 (Nurgiyantoro, 2001:388). Jelaslah $r_{\text {hit }}>r_{t}=0,444$ pada tingkat signifikan 5\%. Dengan demikian, instrumen yang digunakan dalam penelitian ini sebagai alat penelitian data yang sahih.

Butir soal nomor 1 mempunyai koefisien korelasi yang tinggi, 0,740, melebihi batas signifikan 1\%. Hal itu berarti soal nomor 1 mempunyai tingkat kesahihan tinggi antara 0,71 - 0,90 (Poerwadarninta, 1987:178).

1. Pengujian Reliabilitas

Analisis reliabilitas ini yaitu dengan cara menghitung skor untuk tiap-tiap soal bernomor ganjil (Variabel $\mathrm{x}$ ) dan butir soal yang bernomor genap (variabel $\mathrm{y}$ ). Tabulasi data hasil uji coba instrumen penguasaan kosakata siswa kelas XI SMA N 4 Bengkulu. Koefisien tingkat keterpercayaan seluruh tes yang diperoleh tersebut $(0,999)$ termasuk kategori tinggi, maka tes yang diujicobakan itu dinyatakan memiliki tingkat kepercayaan tinggi antara 0,71-0,91.

Dalam analisis reliabilitas tes esei ini, yaitu dengan cara menghitung perskor yang dimana penilainya sudah ditentukan. Analisis data hasil uji coba tes esei penggunaan kosa ata siswa kelas XI SMA Negeri 4 Bengkulu. Analisis hasil uji coba tes esei, dengan menggunakan rumus $\mathrm{K}-\mathrm{R}$. Dari hasil perhitungan diperoleh, $\mathrm{r}_{\text {hit }}$ sebesar 0,588 sedangkan $r$ dalam tabel (rt) dengan signifikan $5 \%$ yaitu 0,444 (Nurgiyantoro, 2001:388). Jelaslah $r_{\text {hit }}>r_{\text {tab }}=0,588>0,444$ pada tingkat signifikan $5 \%$. Dengan demikian, penelitian instrumen ini dapat dinyatakan reliabel untuk tingkat $5 \%$ dengan kata lain instrumen penelitian ini dapat digunakan sebagai alat penelitian data yang terpercaya. 
Korelasi antara Penguasaan Kosakata dengan Kemampuan Menulis Karangan Narasi ...

\section{Pengujian Validitas}

Pengujian validitas tes menggunakan teknik belah dua yaitu dengan cara membagi dua kelompok dari 20 orang siswa, yaitu 10 orang kelompok $X$ (ganjil) dan 10 orang kelompok Y (genap), dengan menggunakan rumus Product Moment. Hasil analisis data menunjukkan bahwa rhit sebesar 0,978 sedangkan $r$ dalam tabel (rt) dengan signifikan 5\% yaitu 0,444 (Nurgiyantoro, 2001:388). Jelas $r_{\text {hit }}>r_{\text {tab }}=0,978>$ 0,444 pada tingkat signifikan $5 \%$. Dengan demikian, instrumen penelitian ini valid untuk ditingkat $5 \%$ dengan kata lain instrumen penelitian ini dapat dipergunakan sebagai alat penelitian data yang sahih.

Butir soal nomor 1 mempunyai koefisien korelasi yang sangat tinggi 0,909, melebihi batas signifikan $1 \%$. Hal itu berarti butir soal tersebut mempunyai tingkat kesahihan yang tinggi antara 0,71-0,90.

\section{Analisis Tingkat Penguasaan Kosakata dan Kemampuan Menulis Karangan \\ Narasi}

Untuk menganalisis data penelitian digunakan analisis statistik dengan rumus rata / rumus "Mean Arimatik (Hadi, 2000:35). Dari nilai rata-rata hitung tes sampel, bila dikonsultasikan pada skala lima untuk mendapatkan perhitungan jumlah frekuensi persentase, skornya berada pada tingkat penguasaan $60 \%$ - 74\%, berarti siswa tersebut memiliki tingkat penguasaan yang cukup dalam penguasaan kosakata bahasa Indonesia.

Dengan melihat hasil analisis data tes tersebut, dapat diketahui bahwa siswa yang memiliki tingkat penguasaan kosakata yang baik sebanyak 35 orang $(22,85 \%)$, siswa yang memiliki tingkat penguasaan kosakata cukup sebanyak 106 orang $(68,39 \%)$, dan siswa yang memiliki tingkat penguasaan kosakata kurang sebanyak 14 orang $(9,03 \%)$.

Kemudian, dari hasil analisis kemampuan menulis karangan narasi, dapat diketahui bahwa siswa yang memiliki tingkat kemampuan menulis karangan narasi yang baik sebanyak 30 orang $(19,35 \%)$, siswa yang memiliki tingkat kemampuan yang cukup sebanyak 91 orang $(58,71 \%)$, siswa yang memiliki tingkat kemampuan kurang sebanyak 33 orang $(21,29 \%)$, dan siswa yang memiliki tingkat kemampuan rendah atau gagal sebanyak 1 orang $(0,65 \%)$. Dengan demikian, berarti hipotesis yang berbunyi siswa SMA Negeri 4 Bengkulu mampu menulis karangan narasi bahasa Indonesia itu dapat dibuktikan dengan kata lain hipotesis diterima.

\section{Hasil Uji Korelasi}

Analisis ini bertujuan untuk mengetahui ada tidaknya korelasi atau hubungan antara penguasaan kosakata dan kemampuan menulis karangan narasi yang diuji dengan menggunakan rumus Product Moment. Dari hasil perhitungan bila dikonsultasikan pada tabel product moment (Nurgiyantoro, 2001:388) untuk $\mathrm{N}=155$ pada taraf signifikan $5 \%$ diperoleh nilai $r_{\text {tab }}=0,159$ dan taraf signifikan $1 \%=0,210$, karena nilai $r_{\text {hit }}=0,724>r_{t}=0,159$ untuk $N=155$ baik pada taraf signifikan $5 \%$ maupun pada taraf signifikan $1 \%$ berarti Ho ditolak, Ha diterima dengan demikian ada hubungan yang signifikan antara penguasaan kosakata bahasa Indonesia dengan kemampuan menulis karangan narasi siswa SMA Negeri 4 Bengkulu. 


\section{PEMBAHASAN}

Hasil uji coba korelasi menunjukkan bahwa terdapat korelasi antara penguasaan kosakata dengan kemampuan menulis karangan narasi siswa kelas XI SMA Negeri 4 Bengkulu. Hal ini dibuktikan dengan $r_{\text {hit }}=0,724>r_{t}=0,159$ pada taraf $5 \%$. Dengan demikian, hipotesis diterima. Dari hasil penelitian ini diperoleh informasi bahwa semakin baik penguasaan kosakata siswa maka akan semakin baik kemampuan menulis karangan narasinya. Hal ini sesuai dengan penelitian terdahulu oleh Hasrar dkk. (2018) dan Suryadi \& Milawasri (2018) bahwa penguasaan kosakata berpengaruh terhadap kemampuan menulis deskripsi dan menulis cerpen.

Dari hasil penelitian ini, diharapkan guru bahasa Indonesia, khususnya guru bahasa Indonesia di SMA Negeri 4 Bengkulu sebelum meminta siswa menulis karangan narasi, terlebih dahulu meminta siswa melakukan kegiatan yang menambah penguasaan kosakata yang berhubungan dengan tulisan narasi. Misalnya diminta membaca beberapa tulisan narasi seperi, cerpen dan novel. Harapannya apabila penguasaan kosakata siswa sudah baik dalam hal tulisan narasi maka siswa akan mampu menulis karangan narasi dengan baik karena sudah memiliki konsep gaya penulisan narasi.

\section{KESIMPULAN DAN SARAN}

Berdasarkan hasil penelitian dan pembahasan yang telah dilakukan, menunjukkan bahwa terdapat korelasi yang tinggi antara penguasaan kosakata dengan kemampuan menulis karangan narasi siswa kelas XI SMA Negeri 4 Bengkulu. Kemudian, penguasaan kosakata bahasa Indonesia siswa SMA Negeri 4 Bengkulu dikategorikan cukup, sesuai dengan kategori cukup apabila berada antara $60 \%-74 \%$. Kemampuan menulis karangan narasi siswa SMA Negeri 4 dikategorikan cukup. Harapannya, bagi guru bahasa Indonesia, sebelum meminta siswa menulis karangan narasi diupayakan terlebih dahulu melakukan kegiatan untuk menambah penguasaan kosakata siswa, misalnya dengan melakukan kegiatan membaca cerpen atau novel. Dengan siswa memiliki penguasaan kosakata yang baik maka hasil menulis karangan narasinya pun akan baik.

\section{DAFTAR PUSTAKA}

Arikunto, S. (2013). Prosedur Penelitian: Suatu Pendekatan Praktik. Jakarta: Rineka Cipta.

Gall, Meredith D., Joyce P. Gall, \& Walter Borg. (2003). Educational Research: An Introduction. Boston: Pearson Education Inc.

Hadi, S. (2000). Metodologi Penelitian. Yogyakarta: Andi Yogyakarta.

Hasrar, H., Dalle, A., \& Usman, M. (2018). Hubungan Penguasaan Kosakata dengan Keterampilan Menulis Karangan Deskriptif Bahasa Jerman Siswa. Eralingua: Jurnal Pendidikan Bahasa Asing Dan Sastra, 2(2). doi:10.26858/eralingua.v2i2.6755

Keraf, G. (2008). Diksi dan Gaya Bahasa. Jakarta: PT Gramedia Pustaka Utama. 
Korelasi antara Penguasaan Kosakata dengan Kemampuan Menulis Karangan Narasi ...

Ningrum, D. J., Suryadi, S., \& Chandra Wardhana, D. E. (2019). Kajian Ujaran Kebencian Di Media Sosial. Jurnal IImiah KORPUS, 2(3), 242. doi:10.33369/jik.v2i3.6779

Noermanzah, N. (2016). Sermon Rhetoric Patterns of President Joko Widodo's Oration in the Occasion of Bung Karno's Oration on June 1, 1945 Commemoration. Journal of Indonesian Language Education and Literary, 1 (2), 10.

Noermanzah, N., Abid, S., \& Aprika, E. (2018). Pengaruh Teknik Send a Problem terhadap Kemampuan Menulis Daftar Pustaka Siswa Kelas Xi SMA Negeri 4 Lubuklinggau. Jurnal Kajian Bahasa, Sastra dan Pengajaran (KIBASP), 1(2), 172. doi:10.31539/kibasp.v1i2.273

Noermanzah, N., Abid, S., \& Septaria, S. (2018). Improving the Ability of Writing a Narrative Charge by Using Animated Images Media Student Class V.B SD Negeri 17 Lubuklinggau. BAHTERA : Jurnal Pendidikan Bahasa dan Sastra, 17(2), 116. doi:10.21009/bahtera.172.9

Nurgiyantoro, B. (2001). Penilaian dalam Pengajaran Bahasa dan Sastra Indonesia.Yogjakarta: BPFE.

Riyanti, S., Susetyo, S., \& Wardhana, D. E. C. (2019). Korelasi antara Minat Baca dengan Kemampuan Menulis Teks Prosedur Kompleks pada Siswa Kelas VXI SMP Negeri Sumber Rejo Kabupaten Musi Rawas. Diksa: Pendidikan Bahasa dan Sastra Indonesia, 5(1), 43. doi:10.33369/diksa.v5i1.9236

Semi, M. A. (1990). Rancangan Pengajaran Bahasa dan Sastra Indonesia. Bandung: Angkasa.

Suryadi, E., \& Milawasri, F. A. (2018). Hubungan Penguasaan Kosakata dengan Kemampuan Menulis Cerpen Mahasiswa FKIP Universitas Tridinanti Program Studi Pendidikan Bahasa dan Sastra Indonesia. Jurnal Bindo Sastra, 2(2), 232. doi:10.32502/jbs.v2i2.1263

Tarigan, D. \& Tarigan, H. G. (1990). Teknik Pengajaran Keterampilan Berbahasa. Bandung: Angkasa. 